\title{
METODE TAGUCHI UNTUK OPTIMALISASI PRODUK PADA RANCANGAN FAKTORIAL
}

\author{
Triastuti Wuryandari $^{1}$, Tatik Widiharih ${ }^{2}$, Sayekti Dewi Anggraini ${ }^{3}$ \\ ${ }^{1,2}$ Staf Pengajar Program Studi Statistika FMIPA UNDIP \\ ${ }^{3}$ Alumni Program Studi Statistika FMIPA UNDIP
}

\begin{abstract}
Taguchi methods represent the effort quality improvement which known as off-line quality control method because the method design quality into every appropriate process and product. Taguchi methods is represent quality repair with attempt "new" methods, its meaning do dissimilar approach giving same belief storey by SPC (Statistical Proces Control), very effective in quality improvement as well as lessening expense of same. Fractional factorial design represent base from Taguchi method by fraction from factorial design. Fractional factorial $3^{\mathrm{k}-\mathrm{p}}$ with 4 factors and defining relations $p=2$ is $3^{4}$ or 81 run become $3^{4-2}$ or 9 blocks with each blocks there are 9 run just eligible one block. The block name that is Orthogonal Array which lessen time and attemp fare. Orthogonal Array used to device of factorial attemp 3 level by 4 factors that is Orthogonal Array $\mathrm{L}_{9}$. Optimalitation product of factorial design $3^{k}$ can be determinate with tables of anova, table of response and tables of Signal to Noise Ratio.
\end{abstract}

Keywords: Taguchi Methods, Signal to Noise Ratio, Orthogonal Array

\section{Pendahuluan}

Di berbagai bidang, suatu penelitian yang berkaitan dengan suatu rancangan produk atau proses, kualitas menjadi hal yang sangat diperhitungkan. Kualitas produk merupakan salah satu faktor yang mempengaruhi persepsi konsumen. Konsumen lebih memilih produk yang kualitasnya baik sehingga peningkatan kualitas dari produk tertentu menjadi hal yang sangat penting ${ }^{[7]}$. Pemanfaatan rancangan percobaan pada proses produksi dapat menunjang keberhasilan suatu proses secara keseluruhan. Rancangan percobaan banyak diterapkan di berbagai bidang seperti pada bidang industri, biologi, farmasi dan lainlainnya. Pengertian rancangan percobaan adalah suatu tes atau serangkaian tes dengan maksud mengamati dan mengidentifikasi perubahan pada output respon yang disebabkan oleh perubahan-perubahan yang dilakukan pada variabel input dari suatu proses ${ }^{[8]}$. Keuntungan rancangan percobaan antara lain dapat digunakan dalam pengendalian proses dan peningkatan atau perbaikan proses. Sebagian besar percobaan meliputi dua faktor atau lebih yang diamati. Percobaan yang melibatkan dua faktor atau lebih disebut percobaan faktorial. Keuntungan dari faktorial adalah mampu mendeteksi respon dari taraf masingmasing faktor dan interaksinya.

Pengendalian kualitas adalah penggunaan teknik dan aktivitas untuk mempertahankan dan memperbaiki kualitas produk atau jasa ${ }^{[6]}$. Terdapat dua pendekatan dalam pengendalian kualitas yaitu On-line Quality Control dan Off-line Quality Control. Usaha-usaha yang tercakup dalam On-line Quality Control adalah pendiagnosaan dan penyesuaian proses, pengontrolan proses, dan inspeksi hasil proses. Usaha-usaha ini adalah pengendalian kualitas yang berlangsung saat proses produksi sedang berjalan. Pengendalian kualitas secara Off-line Quality Control adalah usaha-usaha yang bertujuan mengoptimalkan desain proses dan produk, sebagai pendukung usaha on-line quality control. Usaha ini dilakukan baik sebelum maupun setelah proses.

Salah satu pengendalian kualitas secara Off-line Quality Control adalah Metode Taguchi dengan penggagasnya adalah Genichi Taguchi. Dalam penelitiannya, Taguchi menggunakan desain percobaan yaitu rancangan fraksional factorial. Taguchi menyusun 
Orthogonal Array (OA) untuk tata letak eksperimennya. Tabel OA dapat digunakan untuk menentukan kontribusi setiap faktor yang berpengaruh terhadap kualitas dan dapat diketahui tingkat faktor yang memberikan hasil yang optimal. Dengan OA untuk tata letak eksperimennya, maka tidak semua perlakuan dijalankan atau dengan kata lain, runnya dapat dipersingkat sehingga biaya, waktu dan materi percobaan dapat dikurangi.

\section{Deskripsi Teoritis}

\subsection{Rancangan Faktorial}

Rancangan percobaan bisa dilakukan untuk percobaan dengan faktor tunggal atau faktor ganda. Jika rancangan percobaan diterapkan pada satu faktor, maka disebut percobaan tunggal sedangkan jika percobaan diterapkan untuk multifaktor disebut percobaan faktorial [12]. Dalam percobaan faktorial, selain efek utama, bisa diketahui efek interaksinya. Dalam faktorial setiap faktor terdiri dari 2 tingkat atau lebih. Jika setiap faktor terdiri dari dua tingkat maka dikatakan faktorial $2^{k}$ dan jika setiap faktornya terdiri dari 3 tingkat dikatakan faktorial $3^{k}$. Misalnya suatu percobaan terdiri dari 4 faktor dan masing-masing faktor terdiri dari 2 tingkat, maka banyaknya kombinasi perlakuan adalah $2^{4}=16$. Jika banyaknya faktor 4 dan masing-masing faktor terdiri dari 3 tingkat, maka banyaknya perlakuan adalah $3^{4}=81$. Jika suatu percobaan melibatkan banyak faktor dan seluruh kombinasi perlakuan dicobakan, maka biaya, tenaga dan waktu yang diperlukan semakin besar. Salah satu cara untuk mengurangi run adalah dengan Fractional Factorial.

\subsection{Orthogonal Array $(O A)$}

Orthoganal array (OA) merupakan salah satu bagian fractional factorial experiment (FFE). Sedangkan FFE merupakan percobaan yang hanya menggunakan sebagian dari kondisi total (full factorial experiment). Bagian ini mungkin hanya separuh, seperempat, atau seperdelapan dari percobaan faktorial penuh jika percobaan faktorial $2^{k}$. Sedangkan jika percobaannya $3^{k}$, barangkali hanya sepertiga, sepersembilan, atau seperduapuluh tujuh. OA diciptakan oleh Jaques Hardmand pada tahun 1897, dan mulai diterapkan pada perang dunia II oleh Plackett dan Burman. Pada OA, untuk faktorial $2^{k}$, level rendah dinotasikan dengan "-" dan level tinggi dinotasikan dengan "+" sedangkan untuk percobaannya $3^{k}$, level rendah dinotasikan dengan tanda “ - ", untuk level sedang dinotasikan dengan tanda " 0 ", dan untuk level tinggi dengan tanda " + ". Ada beberapa $\mathrm{OA}$ antara lain untuk 4 run dinotasikan dengan $\mathrm{L}_{4}$ yang dapat digunakan jika masingmasing faktor terdiri dari 2 tingkat dan OA untuk 9 run dinotasikan $\mathrm{L}_{9}$ yang dapat digunakan untuk faktor yang terdiri dari 3 tingkat. Keuntungan OA adalah kemampuan untuk mengevaluasi beberapa faktor dengan jumlah run sedikit. Jika pada percobaan terhadap 4 faktor dengan 3 taraf, menggunakan percobaan faktorial penuh akan diperlukan $3^{4}$ percobaan. Dengan OA akan dapat dikurangi run yang dilakukan sehingga akan mengurangi waktu dan biaya. OA telah menyediakan berbagai matriks untuk pengujian faktor-faktor dengan dua dan tiga taraf dengan kemungkinan pengembangan untuk pengujian multiple taraf ${ }^{[9]}$. Pada tulisan ini hanya dibatasi untuk faktorial tiga taraf. 
Tabel 1. OA L 4

\begin{tabular}{|l|l|l|l|}
\hline Run & A & B & C \\
\hline 1 & -1 & -1 & -1 \\
\hline 2 & -1 & +1 & +1 \\
\hline 3 & +1 & -1 & +1 \\
\hline 4 & +1 & +1 & -1 \\
\hline
\end{tabular}

Tabel 2. OA L9

\begin{tabular}{|l|c|c|c|c|}
\hline Run & A & B & C & D \\
\hline 1 & -1 & -1 & -1 & -1 \\
\hline 2 & -1 & 0 & 0 & 0 \\
\hline 3 & -1 & +1 & +1 & +1 \\
\hline 4 & 0 & -1 & 0 & +1 \\
\hline 5 & 0 & 0 & +1 & -1 \\
\hline 6 & 0 & +1 & -1 & 0 \\
\hline 7 & +1 & -1 & +1 & 0 \\
\hline 8 & +1 & 0 & -1 & +1 \\
\hline 9 & +1 & +1 & 0 & -1 \\
\hline
\end{tabular}

\section{Pembahasan}

\subsection{Rancangan Fraksional Faktorial}

Jika suatu percobaan diselidiki $k$ faktor yang masing-masing mempunyai dua taraf, maka terdapat $2^{\mathrm{k}}$ kombinasi perlakuan dan jika masing-masing faktor terdiri dari 3 taraf maka terdapat $3^{\mathrm{k}}$ kombinasi perlakuan. Kadang-kadang dalam percobaan yang melibatkan banyak faktor, tidak semua perlakuan dicobakan sekaligus karena keterbatasan waktu, biaya ataupun materi percobaan. Jika tidak semua perlakuan dijalankan atau dengan kata lain hanya sebagian saja, maka percobaannya disebut fraksional faktorial. Sebagai contoh rancangan $3^{5}$ membutuhkan 243 amatan yang akan mengestimasi sebuah rata-rata keseluruhan, 5 efek utama, 10 efek interaksi dua-faktor, 10 efek interaksi tiga faktor, 5 interaksi empat faktor dan 1 interaksi lima faktor. Dengan fraksional faktorial, bisa hanya menjalankan sepertiganya, sepersembilannya ataupun seperduapuluh tujuhnya. Penggunaan fraksional faktorial sering dijumpai pada percobaan penyaringan (screening experiment). Salah satu penggunaan fraksional faktorial dijumpai pada metode Taguchi.

\subsection{Metode Taguchi}

Ide atau gagasan dari Dr. Genichi Taguchi mengenai quality engineering telah digunakan selama beberapa tahun di Jepang. Pada tahun 1980-an ide beliau mengenai desain eksperimen telah diperkenalkan di dunia barat. Sasaran quality engineering adalah merancang kualitas ke dalam tiap-tiap produk dan proses yang sesuai. Usaha peningkatan kualitas ini dikenal sebagai metode off-line quality control ${ }^{[6]}$.

Metode Taguchi merupakan perbaikan kualitas dengan metode percobaan "baru", artinya melakukan pendekatan lain yang memberikan tingkat kepercayaan yang sama dengan SPC (Statistical Proces Control). Metode off-line Taguchi sangat efektif dalam peningkatan kualitas dan juga mengurangi biaya. Rekayasa kualitas yang diusulkan Taguchi bertujuan agar performansi produk/prosesnya tidak sensitif atau tangguh terhadap faktor yang sulit dikendalikan. Taguchi memperkenalkan sebuah metode perancangan terintegrasi yang dikenal sebagai tiga tahapan Metode Taguchi ${ }^{[9]}$ sebagai berikut:
a. Perancangan Sistem (System Design)
b. Perancangan Parameter (Parameter Design)
c. Perancangan Toleransi (Tolerance Design)

\subsection{Signal to Noise Ratio(S/N)}

Signal to Noise Ratio( $S / N)$ digunakan untuk mengidentifikasi faktor-faktor yang mempengaruhi variasi suatu respon. Taguchi menciptakan transformasi dari pengulangan data ke nilai lain yang merupakan ukuran dari variasi yang ada. Tranformasinya adalah 
signal to noise ratio atau rasio S/N. Perhitungan Rasio S/N yang dilakukan tergantung dari karakteristik mutu yang dituju. Karakteristik kualitas adalah hasil dari proses yang berkaitan dengan kualitas.Taguchi membagi karakteristik kualitas menjadi 3 kategori, yaitu:

1. Nominal is the best

Merupakan karakteristik kualitas dengan nilai yang dapat positif maupun negatif. Contoh: ketebalan, berat, tekanan, temperatur, dimensi produk, dan sebagainya.

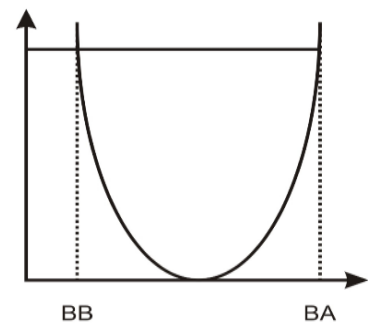

Gambar 1. Nominal is the best

Nilai $\mathrm{S} / \mathrm{N}$ untuk nominal is the best adalah:

$$
\begin{aligned}
& S / N R=10 \log _{10} \frac{\mu^{2}}{\sigma^{2}} \\
& \mu=\frac{1}{n} \sum_{i=1}^{n} y_{i}^{2} \\
& \sigma^{2}=\frac{1}{n-1} \sum_{i=1}^{n}\left(y_{i}-\mu\right)^{2}
\end{aligned}
$$

dengan :

$\mathrm{n} \quad$ = banyaknya ulangan dalam tiap eksperimen

$\mathrm{y} \quad=$ nilai pada setiap run

$\mu \quad=$ rata-rata dari setiap run

$\sigma^{2}=$ deviasi dari setiap run

2. Lower is better

Merupakan karakteristik terukur non negatif dengan nilai ideal nol. Karakteristik dimana nilai yang dituju adalah suatu nilai terkecil. Contoh: jumlah produk cacat/gagal, pemborosan energi, kebisingan, limbah, dan lain-lain.

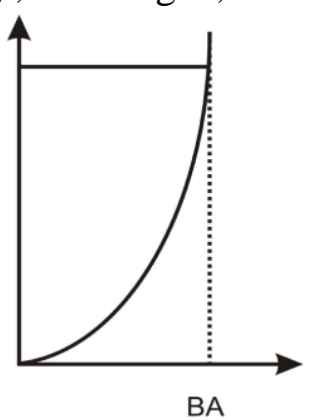

Gambar 2. Lower is better

Nilai S/N untuk karakteristik kualitas Lower is better adalah:

$$
S / N R=-10 \log _{10}\left[\frac{1}{n} \sum_{i=1}^{n} y_{i}^{2}\right]
$$




\section{Higher is better}

Merupakan karakteristik terukur dengan nilai non negatif dengan nilai ideal tak terhingga. Contohnya: kekuatan bangunan, ketahanan terhadap korosi, pemakaian bahan bakar per km, umur pemakaian produk, dan lainnya.

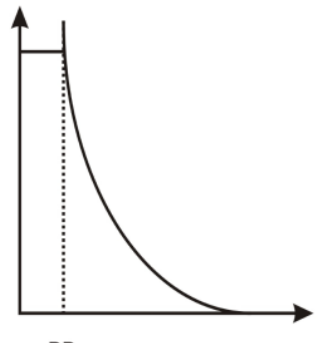

Gambar 3. Higher is better

Nilai S/N untuk karakteristik kualitas Higher is better adalah:

$$
S / N R=-10 \log _{10}\left[\frac{1}{n} \sum_{i=1}^{n} \frac{1}{y_{i}^{2}}\right]
$$

\subsection{Tabel Respon}

Perhitungan efek masing-masing faktor terhadap respon, dapat digunakan Tabel Respon. Tabel Respon berisi perhitungan efek dari hasil pengamatan yang dirancang. Tabel respon menyediakan cara yang cepat untuk menaksir efek utama itu. Efek dari beberapa faktor A pada respon y adalah rata-rata perubahan dalam respon yang dihasilkan pada saat pengaturan faktor A menuju ke taraf rendah, ke taraf sedang, dan ke taraf tinggi untuk tiga taraf. Tabel OA dengan hasil adalah sebagai berikut:

Tabel 3. OA $\mathrm{L}_{9}$ dengan Hasil Observasi

\begin{tabular}{|c|c|c|c|c|c|}
\hline \multirow[b]{2}{*}{ Eksperimen } & \multicolumn{4}{|c|}{ Perlakuan untuk } & \multirow{2}{*}{$\begin{array}{c}\text { Hasil } \\
\text { Observasi }\end{array}$} \\
\hline & A & $\mathrm{B}$ & $\mathrm{C}$ & $\mathrm{D}$ & \\
\hline 1 & -1 & -1 & -1 & -1 & $\mathrm{y}_{1}$ \\
\hline 2 & -1 & 0 & 0 & 0 & $\mathrm{y}_{2}$ \\
\hline 3 & -1 & 1 & 1 & 1 & $\mathrm{y}_{3}$ \\
\hline 4 & 0 & -1 & 0 & 1 & $\mathrm{y}_{4}$ \\
\hline 5 & 0 & 0 & 1 & -1 & $\mathrm{y}_{5}$ \\
\hline 6 & 0 & 1 & -1 & 0 & $\mathrm{y}_{6}$ \\
\hline 7 & 1 & -1 & 1 & 0 & $\mathrm{y}_{7}$ \\
\hline 8 & 1 & 0 & -1 & 1 & $\mathrm{y}_{8}$ \\
\hline 9 & 1 & 1 & 0 & -1 & $\mathrm{y}_{9}$ \\
\hline
\end{tabular}

Efek faktor A pada $\mathrm{Y}$ adalah paling besar diantara $\left(\overline{\mathrm{A}}_{1}, \overline{\mathrm{A}}_{2}, \overline{\mathrm{A}}_{3}\right)$ dikurangi yang mempunyai nilai terkecil diantara $\left(\overline{\mathrm{A}}_{1}, \overline{\mathrm{A}}_{2}, \overline{\mathrm{A}}_{3}\right)$ dengan:

$$
\begin{aligned}
& \overline{A_{1}}=\frac{y_{1}+y_{2}+y_{3}}{3} \\
& \overline{A_{2}}=\frac{y_{4}+y_{5}+y_{6}}{3}
\end{aligned}
$$




$$
\overline{A_{3}}=\frac{y_{7}+y_{8}+y_{9}}{3}
$$

Efek dari B diperoleh dari nilai paling besar dikurangi yang mempunyai nilai terkecil diantara dengan:

$$
\begin{aligned}
& \overline{B_{1}}=\frac{y_{1}+y_{4}+y_{7}}{3} \\
& \overline{B_{2}}=\frac{y_{2}+y_{5}+y_{8}}{3} \\
& \overline{B_{3}}=\frac{y_{3}+y_{5}+y_{9}}{3}
\end{aligned}
$$

Efek dari $\mathrm{C}$ diperoleh dari nilai paling besar dikurangi yang mempunyai nilai terkecil diantara dengan:

$$
\begin{aligned}
& \overline{C_{1}}=\frac{y_{1}+y_{6}+y_{8}}{3} \\
& \overline{C_{2}}=\frac{y_{2}+y_{4}+y_{9}}{3} \\
& \overline{C_{3}}=\frac{y_{3}+y_{5}+y_{7}}{3}
\end{aligned}
$$

\begin{tabular}{|c|c|c|c|c|c|c|c|c|c|c|c|c|c|c|}
\hline \multirow{2}{*}{$\begin{array}{c}\text { Random } \\
\text { Order }\end{array}$} & \multirow{2}{*}{ Run } & \multirow{2}{*}{$\begin{array}{l}\text { Observed } \\
\text { Response }\end{array}$} & \multicolumn{3}{|c|}{ A } & \multicolumn{3}{|c|}{$\mathrm{B}$} & \multicolumn{3}{|c|}{$\mathrm{C}$} & \multicolumn{3}{|c|}{$\mathrm{D}$} \\
\hline & & & 1 & 2 & 3 & 1 & 2 & 3 & 1 & 2 & 3 & 1 & 2 & 3 \\
\hline & 1 & $\mathrm{y}_{1}$ & $\mathrm{y}_{11}$ & - & - & $\mathrm{y}_{11}$ & - & - & $\mathrm{y}_{11}$ & - & - & $\mathrm{y}_{11}$ & - & - \\
\hline & 2 & $\mathrm{y}_{2}$ & $\mathrm{y}_{21}$ & - & - & - & $\mathrm{y}_{21}$ & - & - & $Y_{22}$ & - & - & $\mathrm{y}_{22}$ & - \\
\hline & 3 & $\mathrm{y}_{3}$ & $\mathrm{y}_{31}$ & - & - & - & - & $\mathrm{y}_{33}$ & - & - & $\mathrm{y}_{33}$ & - & - & $\mathrm{y}_{33}$ \\
\hline & 4 & $\mathrm{y}_{4}$ & - & $\mathrm{y}_{42}$ & - & $\mathrm{y}_{41}$ & - & - & - & $Y_{42}$ & - & - & - & $\mathrm{y}_{43}$ \\
\hline & 5 & $\mathrm{y}_{5}$ & - & $\mathrm{y}_{52}$ & - & - & $\mathrm{y}_{52}$ & - & - & - & $Y_{53}$ & - & $\mathrm{y}_{52}$ & - \\
\hline & 6 & $\mathrm{y}_{6}$ & - & $\mathrm{y}_{62}$ & - & - & - & $\mathrm{y}_{63}$ & $\mathrm{y}_{6}$ & - & - & $\mathrm{y}_{61}$ & - & - \\
\hline & 7 & $\mathrm{y}_{7}$ & - & - & $\mathrm{y}_{73}$ & $\mathrm{y}_{71}$ & - & - & - & - & $Y_{73}$ & - & $\mathrm{y}_{72}$ & - \\
\hline & 8 & $\mathrm{y}_{8}$ & - & - & $\mathrm{y}_{83}$ & - & $\mathrm{y}_{82}$ & - & $\mathrm{y}_{8}$ & - & - & - & - & $\mathrm{y}_{83}$ \\
\hline & 9 & $\mathrm{y}_{9}$ & - & - & $\mathrm{y}_{93}$ & - & - & $\mathrm{y}_{93}$ & - & $Y_{92}$ & - & $\mathrm{y}_{91}$ & - & - \\
\hline \multicolumn{2}{|c|}{ Total } & \multicolumn{13}{|c|}{ (sum of observations in columns above goes here) } \\
\hline \multicolumn{3}{|c|}{ No. of data values 9} & 3 & 3 & 3 & 3 & 3 & 3 & 3 & 3 & 3 & 3 & 3 & 3 \\
\hline \multicolumn{2}{|c|}{ Average } & $\bar{y}$ & $\overline{\mathrm{A}} \cdot 1$ & $\overline{\mathrm{A}} \cdot 2$ & $\bar{A} \cdot 3$ & $\overline{\overline{B_{11}}}$ & $\overline{\overline{B_{22}}}$ & $\overline{\overline{B_{33}}}$ & $\overline{\overline{C_{.1}}}$ & $\overline{\overline{C_{.2}}}$ & $\overline{\overline{C_{33}}}$ & $\overline{D_{x_{1}}}$ & $\overline{D_{22}}$ & $\overline{\overline{D_{33}}}$ \\
\hline \multicolumn{3}{|c|}{ Estimated main effect } & \multicolumn{3}{|c|}{$\begin{array}{l}\text { Terbesar- } \\
\text { terkecil }\end{array}$} & \multicolumn{3}{|c|}{$\begin{array}{l}\text { Terbesar- } \\
\text { terkecil }\end{array}$} & \multicolumn{3}{|c|}{ Terbesar-terkecil } & \multicolumn{3}{|c|}{$\begin{array}{l}\text { Terbesar- } \\
\text { terkecil }\end{array}$} \\
\hline
\end{tabular}

Efek dari D diperoleh dari nilai paling besar dikurangi yang mempunyai nilai terkecil diantara dengan:

$$
\begin{aligned}
& \overline{D_{1}}=\frac{y_{1}+y_{6}+y_{9}}{3} \\
& \overline{D_{2}}=\frac{y_{2}+y_{5}+y_{7}}{3} \\
& \overline{D_{3}}=\frac{y_{3}+y_{4}+y_{8}}{3}
\end{aligned}
$$

Tabel 4. Tabel Respon untuk Empat Faktor

Untuk kolom Random Order, berfungsi untuk mengacak urutan percobaan (run) dengan tujuan memperkecil penyimpangan (bias). 


\subsection{Contoh terapan Metode Taguchi dengan data Hasil Percobaan 3 Taraf}

Suatu proses produksi diduga dipengaruhi oleh 4 faktor (persentase bahan, temperatur, tekanan injeksi, kecepatan mesin). Masing-masing faktor terdiri dari 3 taraf. Diamati banyaknya produk yang cacat untuk setiap 100 produk, diperoleh hasil sebagai berikut:

Tabel 5. 4 Faktor Masing-masing 3 Taraf

\begin{tabular}{|c|c|c|c|c|}
\hline \multicolumn{2}{|c|}{ Faktor } & \multicolumn{3}{|c|}{ Taraf } \\
\cline { 3 - 5 } & & -1 & 0 & 1 \\
\hline A & Persentase bahan & 60 & 70 & 80 \\
\hline B & Temperatur & 217 & 225 & 233 \\
\hline C & Tekanan injeksi & 92 & 93 & 94 \\
\hline
\end{tabular}

Tabel 6. Banyaknya Cacat dari 4 Faktor

\begin{tabular}{|c|c|c|c|c|c|c|c|}
\hline & \multicolumn{4}{|c|}{ Faktor Terkontrol } & \multicolumn{3}{c|}{ Jumlah Cacat } \\
\cline { 2 - 8 } Order & A & B & C & D & -1 & 0 & 1 \\
\hline 1 & -1 & -1 & -1 & -1 & 14 & 17 & 15 \\
\hline 2 & -1 & 0 & 0 & 0 & 4 & 3 & 1 \\
\hline 3 & -1 & 1 & 1 & 1 & 61 & 6 & 56 \\
\hline 4 & 0 & -1 & 0 & 1 & 8 & 7 & 5 \\
\hline 5 & 0 & 0 & 1 & -1 & 14 & 16 & 17 \\
\hline 6 & 0 & 1 & -1 & 0 & 27 & 19 & 22 \\
\hline 7 & 1 & -1 & 1 & 0 & 0 & 1 & 0 \\
\hline 8 & 1 & 0 & -1 & 1 & 0 & 1 & 1 \\
\hline 9 & 1 & 1 & 0 & -1 & 9 & 7 & 6 \\
\hline
\end{tabular}

Tabel 7. 4 Efek Faktor

\begin{tabular}{|c|c|c|c|c|}
\hline Efek Faktor & Taraf & Jumlah & Rata-rata & Efek Faktor \\
\hline \multirow{3}{*}{ A } & -1 & 231 & 25,7 & \multirow{2}{*}{22,9} \\
\cline { 2 - 4 } & 0 & 135 & 15 & \\
\cline { 2 - 4 } & 1 & 25 & 2,8 & \\
\hline \multirow{3}{*}{ B } & -1 & 67 & 7,4 & \multirow{2}{*}{23,4} \\
\cline { 2 - 4 } & 0 & 67 & 6,3 & \multirow{2}{*}{24,44} \\
\cline { 2 - 4 } & 1 & 267 & 29,7 & \\
\hline \multirow{3}{*}{ C } & -1 & 116 & 12,9 & \multirow{2}{*}{13,5} \\
\cline { 2 - 4 } & 0 & 5 & 0,56 & \\
\cline { 2 - 4 } & 1 & 225 & 25 & \\
\hline \multirow{3}{*}{ D } & -1 & 115 & 12,8 & \multirow{2}{*}{8,6} \\
\cline { 2 - 4 } & 0 & 77 & 22,1 & \\
\cline { 2 - 4 } & 1 & 199 & 29 & \\
\hline
\end{tabular}


Terlihat bahwa pada Efek faktor A dengan taraf -1 mempunyai nilai rata-rata yaitu 25,7, efek faktor A dengan taraf 0 yaitu 15, dan efek faktor A dengan taraf 1 yaitu 2,8. Efek faktor A sebesar 22,9, faktor B sebesar 23,4, faktor C sebesar 24,44 dan faktor D sebesar 13,5. Dengan menggunakan grafik diperoleh:

Main Effects Plot - Data Means for cacat

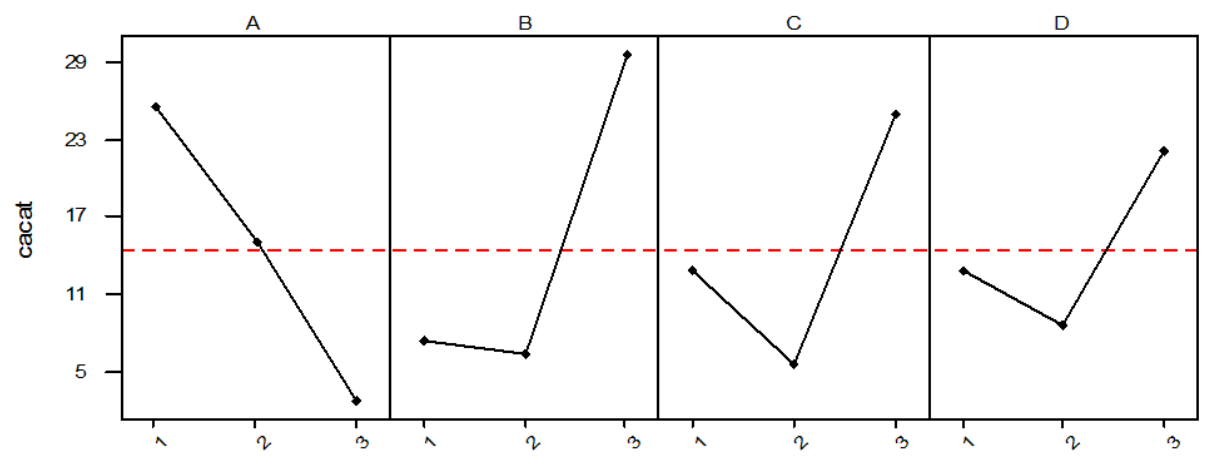

Gambar 4. Plot Efek (A, B, C, D) dari Data Rata-Rata Banyaknya Cacat

Terlihat bahwa pada efek faktor A taraf -1, taraf 0 dan taraf 1 mempunyai perbedaan nilai yang cukup signifikan terlihat dari panjang garis. Dari Keempat faktor memiliki perbedaan yang cukup signifikan, terlihat dengan panjang garis antar faktor.

Untuk mengetahui faktor mana saja yang berpengeruh terhadap banyaknya produk yang cacat, digunakan Tabel Anova dengan karakteristik Smaller is better sebagai berikut:

Tabel 8. Tabel Anova Dari 4 Faktor Dengan Metode Taguchi

\begin{tabular}{|l|c|c|c|c|c|}
\hline \multicolumn{1}{|c|}{ Sumber Variansi } & Jumlah Kuadrat & $\mathrm{Db}$ & Kuadrat Rata-rata & $\mathrm{F}_{0}$ & P-Value \\
\hline A (persentase bahan) & 2361,18518519 & 2 & 1180,592593 & 297,91 & 0,0001 \\
\hline B (temperatur) & 3118,518519 & 2 & 1559,259259 & 393,46 & 0,0001 \\
\hline C (tekanan injeksi ) & 1735,62963 & 2 & 867,8148148 & 218,98 & 0,0001 \\
\hline D (kec. Mesin) & 866,0740741 & 2 & 433,037037 & 109,27 & 0,0001 \\
\hline Error & 71,33333333 & 8 & 3,96296296 & & \\
\hline Total & 8152,740741 & 26 & & & \\
\hline
\end{tabular}

Hipotesis yang bisa diambil:

1. $H_{0}: A_{1}=A_{2}=A_{3}=0$ ( pesentase bahan tidak berpengaruh terhadap kecacatan produk)

$H_{1}$ : paling sedikit ada 1 Ai yang tidak sama dengan 0

2. $H_{0}: B_{1}=B_{2}=B_{3}=0$ ( temperatur berpengaruh terhadap kecacatan produk)

$H_{1}$ :paling sedikit ada $1 \mathrm{Bi}$ yang tidak sama dengan 0 
3. $H_{0}: C_{1}=C_{2}=C_{3}=0$ ( tekanan injeksi tidak berpengaruh terhadap kecacatan produk) $H_{1}$ : paling sedikit ada $1 \mathrm{Ci}$ yang tidak sama dengan 0

4. $H_{0}: D_{1}=D_{2}=D_{3}=0$ ( kecepatan mesin tidak berpengaruh terhadap kecacatan produk) $H_{1}$ :paling sedikit ada 1 Di yang tidak sama dengan 0

Statistik uji: $F_{0}=\frac{\text { KTfaktor }}{K T G}$

Kriteria uji: $H_{0}$ ditolak jika $F_{0}>F_{\text {tabel }}$ atau $H_{0}$ ditolak jika p-value $<\alpha=0,05$

Dari tabel 8, terlihat bahwa semua efek utama yaitu A (persentase bahan), B (temperatur), C (tekanan injeksi), dan D (kecepatan mesin) berpengaruh terhadap kecacatan produk, dengan nilai R-Square $=0,991250$ artinya keragaman cacat pada produk disebabkan oleh persentase bahan, temperatur, tekanan injeksi, dan kecepatan mesin sebesar 99,125\%, sedangkan $0,875 \%$ dipengaruhi faktor lain dengan koefisien keragaman (KK) sebesar $13,74665 \%$.

Uji lanjut dengan metode LSD dilakukan pada semua efek utama karena secara signifikan mempengaruhi cacat pada produk berdasarkan hasil analisis sebagai berikut:

- Faktor A

Perbandingan dari setiap pasangan taraf faktor A disajikan sebagai berikut:

$\begin{array}{lll}\mathrm{A}_{1} & \mathrm{~A}_{2} & \mathrm{~A}_{3}\end{array}$

$25,6667 \quad 15,00 \quad 2,7778$

Faktor A (persentase bahan) taraf rendah $\left(\mathrm{A}_{3}\right)$ mempunyai efek menghasilkan produk cacat paling rendah yaitu 2,7778, dan secara statistik berbeda dengan efek faktor lainnya.

- Faktor B

Perbandingan dari setiap pasangan taraf faktor B disajikan sebagai berikut:

$\begin{array}{lll}\mathrm{B}_{3} & \mathrm{~B}_{1} & \mathrm{~B}_{2}\end{array}$

$29,6667 \quad 7,4444 \quad 6,3333$

Faktor B (temperatur) taraf rendah $\left(\mathrm{B}_{2}\right)$ mempunyai efek menghasilkan produk cacat paling rendah yaitu 6,3333 , dan secara statistik tidak berbeda dengan efek factor $B_{1}$, tetapi berbeda dengan $\mathrm{B}_{3}$.

- Faktor C

Perbandingan dari setiap pasangan taraf faktor $\mathrm{C}$ disajikan sebagai berikut:

$\mathrm{C}_{3} \quad \mathrm{C}_{1} \quad \mathrm{C}_{2}$

$25,000 \quad 12,8889 \quad 5,5556$

Faktor $\mathrm{C}$ taraf rendah $\left(\mathrm{C}_{2}\right)$ mempunyai efek menghasilkan produk cacat paling rendah yaitu 5,5556, dan secara statistik berbeda dengan efek faktor $C$ lainnya.

- Faktor D

Perbandingan dari setiap pasangan taraf faktor D disajikan sebagai berikut:
$\mathrm{D}_{3}$
$\mathrm{D}_{1}$
$\mathrm{D}_{2}$

$22,1111 \quad 12,7776 \quad 8,5556$

Faktor A taraf rendah $\left(\mathrm{D}_{2}\right)$ mempunyai efek menghasilkan produk cacat paling rendah yaitu 8,5556 , dan secara statistik berbeda dengan efek faktor D lainnya. 
Dengan menggunakan program Minitab 13 diperoleh tabel S/NR sebagai berikut:

Tabel 9. Tabel S/NR Lengkap untuk smaller is better

\begin{tabular}{|c|c|c|c|c|c|}
\hline A & B & C & D & cacat & SNR \\
\hline-1 & -1 & -1 & -1 & 14 & $-23,741$ \\
\hline-1 & 0 & 0 & 0 & 4 & $-9,3785$ \\
\hline-1 & 1 & 1 & 1 & 61 & $-35,423$ \\
\hline 0 & -1 & 0 & 1 & 8 & $-16,628$ \\
\hline 0 & 0 & 1 & -1 & 14 & $-23,927$ \\
\hline 0 & 1 & -1 & 0 & 27 & $-27,199$ \\
\hline 1 & -1 & 2 & 0 & 0 & 4,7712 \\
\hline 1 & 0 & -1 & 1 & 0 & 1,7609 \\
\hline 1 & 1 & 0 & -1 & 9 & $-17,43$ \\
\hline
\end{tabular}

Tabel 10. Tabel S/NR untuk smaller is better

\begin{tabular}{|c|c|c|c|c|}
\hline Taraf & A & B & C & D \\
\hline 1 & $-22,8467$ & $-11,8659$ & $-16,3931$ & $-21,6994$ \\
\hline 2 & $-22,5845$ & $-10,5149$ & $-14,4787$ & $-10,602$ \\
\hline 3 & $-3,6326$ & $-26,6893$ & $-18,1929$ & $-16,7632$ \\
\hline Delta & 19,215 & 16,169 & 3,7142 & 11,0974 \\
\hline Rank & 1 & 2 & 4 & 3 \\
\hline
\end{tabular}

- Efek faktor A

Taraf -1 mempunyai nilai S/NR yaitu $-22,8467$, taraf 0 mempunyai nilai S/NR yaitu $-22,5845$, dan taraf 1 yaitu $-3,6326$, dari hasil terlihat bahwa taraf 1 memberikan nilai S/NR paling besar, itu berarti bahwa taraf 1 memberikan pengaruh terhadap kecacatan produk paling kecil.

- Efek faktor B

Taraf -1 mempunyai nilai S/NR yaitu $-11,8659$, taraf 0 mempunyai nilai S/NR yaitu $-10,5149$, dan taraf 1 yaitu $-26,6893$, dari hasil terlihat bahwa taraf 0 memberikan nilai S/NR paling besar, itu berarti bahwa taraf 0 memberikan pengaruh terhadap kecacatan produk paling kecil.

- Efek faktor C

Taraf -1 mempunyai nilai S/NR yaitu $-16,3931$, taraf 0 mempunyai nilai S/NR yaitu $-14,4787$, dan taraf 1 yaitu $-18,1929$, dari hasil terlihat bahwa taraf 0 memberikan nilai S/NR paling besar, itu berarti bahwa taraf 1 memberikan pengaruh terhadap kecacatan produk paling kecil.

- Efek faktor D

Taraf -1 mempunyai nilai S/NR yaitu $-21,6994$, taraf 0 mempunyai nilai S/NR yaitu $-10,602$, dan taraf 1 yaitu $-16,7632$, dari hasil terlihat bahwa taraf 0 memberikan nilai S/NR paling besar, itu berarti bahwa taraf 0 memberikan pengaruh terhadap kecacatan produk paling kecil. 
Grafik Main Efek untuk S/NR

Main Effects Plot for S/N Ratios

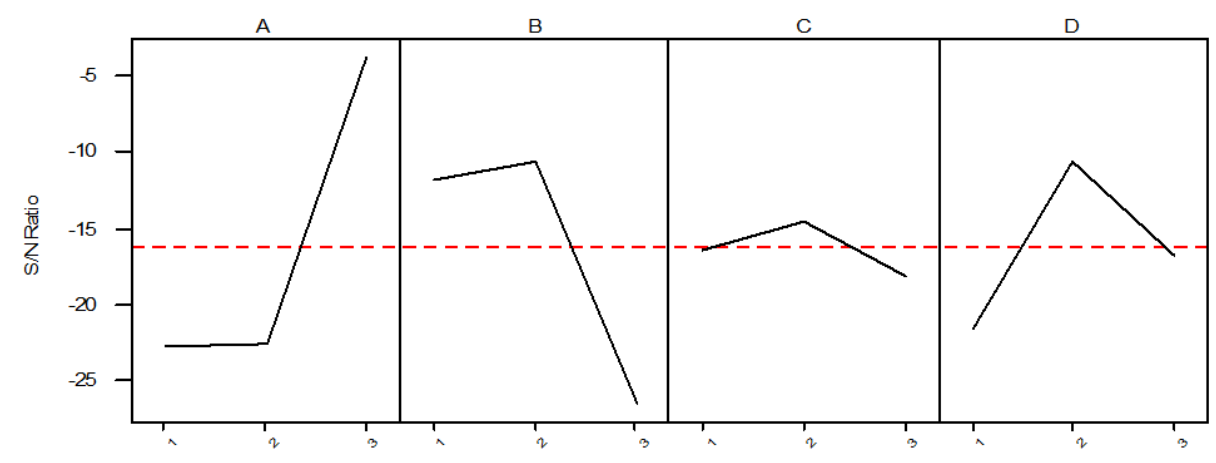

Gambar 5. Plot Efek Pokok S/N Ratio

Selain dari Tabel S/NR, untuk melihat efek utama yang memberikan efek paling kecil adalah menggunakan Grafik Tabel Main Effect untuk S/NR. Dari Grafik tersebut dapat dilihat bahwa pada efek $A_{3}, B_{2}, C_{2}$, dan $D_{2}$ memberikan pengaruh terhadap kecacatan paling kecil.

\section{Kesimpulan}

Metode Taguchi merupakan metode untuk peningkatan kualitas yang dilakukan sebelum proses produksi terjadi atau disebut off-line quality control. Karakteristik kualitas pada metode Taguchi ada 3 yaitu Nominal is the best, Lower is better, Higher is better. Penggunaan karakteristik tersebut berbeda-beda tergantung pada faktor yang akan diteliti. Metode Taguchi menggunakan alat bantu yaitu orthogonal array yang dapat mengurangi run sehingga mengurangi waktu dan biaya percobaan. Untuk menentukan faktor yang paling optimal dalam suatu produk dengan melihat hasil perhitungan dari Signal to Noise Ratio (SNR). SNR untuk setiap percobaan berbeda-beda tergantung karakteristik kualitasnya.

\section{DAFTAR PUSTAKA}

1. Ariani, D.W., Pengendalian Kualitas Statistik, Andy Offset, Yogyakarta, 2003.

2. Bagchi, T.P., Taguchi Method Explained : Practical Step to Robust Design, Prentice Hall of India Privative Limited, New Delhi, 1993.

3. Cowdon, D.J., Statistical Methods in QC, Prentice Hall Inc., NewYork, 1957.

4. Gaspersz, V., Metode Analisis untuk Peningkatan Kualitas, PT. Gramedia Pustaka Utama, Jakarta, 2001.

5. Julianingsih, D. dan Sugianto, D., Penentuan Komposisi Bahan Baku Optimal, 2004.

6. Mitra, A., Fundamentals of Quality Control and Improvement, Macmillan Publishing Company, New York, 1993.

7. Montgomery, D.C., Design and Analysis of Experiments, Sixth Edition, John Wiley \& Sons Inc., Singapore, 2005. 
8. Montgomery, D.C., Introduction to Statistical Quality Control, John Wiley \& Sons Inc., Singapore, 2001.

9. Ross. P.J., Taguchi Techniques for Quality Engineering, $2^{\text {nd }}$ Edition, Mc Graw - Hill Companies Inc., New York, 1996.

10. Wahyudi, D., Optimasi Proses Injeksi dengan Metode Taguchi, Jurnal Teknik Mesin, 2001, Vol.3, No.1: 24-28.

11. Wahyudi, D., Produk Kecap X dengan Metode Taguchi, Jurnal Teknik Industri, 2004, Vol.6, No.2: 121-133.

12. Widiharih, T., Buku Ajar Rancangan Percobaan, Program Studi Statistika Jurusan Matematika FMIPA Undip Semarang, 2007. 